\title{
Osvojení zdravého životního stylu je podmínkou účinnosti léčby a prevence aterosklerotické vaskulární choroby
}

\author{
Jaroslav Šimon
}

Centrum preventivní kardiologie, II. interní klinika, Lékařská fakulta Univerzity Karlovy, Plzeň, Česká republika

Je vědecky zcela prokázáno, že odborně a profesionálně řízená intervence faktorů životního stylu zaměřena na nekouření, zvýšení tělesné aktivity, zdravou výživu, redukci tělesné hmotnosti, př́ípadně na prevenci vzniku obezity, je pro snížení nemocnosti a úmrtnosti na aterosklerotické vaskulární choroby stejně důležitá jako farmakologická léčba. Je to podpora, podněcování, lidově řečeno „fedrování zdraví, na což má angličtina stručný výraz, který jsme již běžně zařadili mezi oblíbené anglicismy „health promotion“.

Evropská kardiologická společnost vytvořila program nazvaný EuroAction, ${ }^{(1)}$ který vznikl na bázi poznatků ze studií EUROASPIRE I a II, ${ }^{(2,3)}$ které testovaly implementaci evropských a národních doporučených postupů do klinické praxe. ${ }^{(4)}$ Pomineme-li medikamentózní léčbu, bez níž se neobejdeme v sekundární prevenci pacientů po prodělané koronární př́íhodě, byly jako hlavní cíle pro primární prevenci vytýčeny - naučit populaci, aby plně porozuměla tomu, co je to kardiovaskulární riziko a osvojila si názor:

- Že zdravý životní styl sníží kardiovaskulární riziko,

- Že nekouření je jednou ze základních podmínek prevence,

- Že je nutno si osvojit zdravé stravovací návyky,

- Že je nutno se pravidelně věnovat tělesným aktivitám spojeným s chưzí (popř. během),

- Že je nutno znát svůj krevní tlak, případně koncentraci cholesterolu v krvi a podřídit se lékařským doporučením $\mathrm{k}$ normalizaci těchto faktorů,

- že je nutno umět se vyrovnávat s emočními stresovými faktory, naučit se relaxovat, uvažovat pozitivně a učit se zvládat úzkost a depresi.

Adresa: prof. MUDr. Jaroslav Šimon, DrSc., Centrum preventivní kardiologie, II. interní klinika, Lékařská fakulta Univerzity Karlovy, E. Beneše 13, 30599 Plzeň, Česká republika e-mail: Jaroslav.Simon@lfp.cuni.cz
Nelze předvídat, co ukáže $\mathrm{v}$ př́ítím roce studie EUROASPIRE III, u které jsme sběr českých údajů z pracovišt v Plzni a Praze ukončili; nicméně můžeme předpokládat, že farmakoterapie se výrazně zlepšila, ale intervence $\mathrm{v}$ oblasti životního stylu, snad s výjimkou kouření, zůstává nedostatečná a neúčinná i u osob, které v naprosté většině při akutní koronární příhodě prodělaly revaskularizaci.

Metodika intervence faktorů životního stylu byla $\mathrm{u}$ nás vypracovaná $\mathrm{v}$ bývalém Výzkumném ústavu balneologickém v Mariánských Lázních. Prokázalo se, že se $\mathrm{v}$ průběhu profesionálně vedeného komplexního rehabilitačního programu v primární prevenci podařilo významně snížit všechny konvenční rizikové faktory, a to i bez farmakoterapie, a snízit i BMI $\left(\mathrm{kg} / \mathrm{m}^{2}\right) .{ }^{(5)}$ Bohužel, tento účinek měl krátké trvání, pouze 3-7 měsíců.

Je nepochybné, že trvalé změny životního stylu lze dosáhnout pouze přijetím životní filozofie, že udržení zdraví je životní prioritou, přesto, že nakonec všichni zemřeme (ale nemusí to být tak zrovna brzy).

Jedním $z$ průkazů o tom, že rizikové faktory (RF) životního stylu lze nejen snížit, ale dlouhodobě, prakticky celoživotně udržet, je známá Adventist Health Study, probíhající po řadu desítiletí v Kalifornii (School of Public Health, Loma Linda University). Práce Frasera, Willeta, Ornishe a dalších ${ }^{(6-10)}$ ukázaly u příslušníků této protestantské církve na celém světě mimořádně nízkou nemocnost a úmrtnost jak na kardiovaskulární choroby, tak i na ostatní chronické neinfekční choroby, včetně nádorů s častým výskytem v populaci (plicních karcinomů, karcinomů mammy, prostaty a močového měchýře). Incidence fatálních i nefatálních kardiovaskulárních příhod byla zhruba o 50 \% nižší než ve známém projektu „Stanford Five-City Project“, rovněž probíhajícím v Kalifornii. U nás (resp. na Slovensku) se RF u vegetariánů (což byli většinou př́íslušníci Církve adventistů 7. dne) zabývala M. Krajčovičová. Několik jejích prací vyšlo v minulých letech i v Cor et Vasa. ${ }^{(1)}$ Zjistila, že potrava bohatá na sacharidy s nízkým glykemickým indexem a vysokým obsahem vlákniny udržuje inzulinovou senzitivitu a brání postprandiálnímu vzestupu glykemie. Přitom obě skupiny byly dobře srovnatelné. Osoby zařazené do kontrolní 
skupiny konzumovaly smíšenou stravu, byly nekuřáci a abstinenti a vesměs dosáhly vyššího vzdělání.

V tomto čísle Cor et Vasa vychází práce Slavička a spol., ${ }^{(12)}$ která prokazuje účinek týdenních rekondičních pobytů u dobrovolníků (adventistů i neadventistů) vegetariánů i příznivců smíšené stravy, u nichž byl zaváděn životní styl nazvaný akronymem NEW START (Nutrition, Exercise, Water, Sunshine, Temperance, Air, Rest, Trust). Je to životní styl odpovídající všem doporučením pro primární i sekundární prevenci aterosklerotické vaskulární choroby. Při vstupu do studie adventisté měli od počátku nižší rizikový profil, který odpovídá výše citovaným studiím Adventist Health Study; také skupina ostatních včetně vegetariánů. Výsledky ukázaly, že pouhý týdenní rekondiční program významně snížil všechny standardní $\mathrm{RF}$, a to $\mathrm{z}$ úrovně normálních na nižší normální koncentrace.

Poslední analýza údajů EUROASPIRE II, zabývající se rehabilitací a modifikací RF životního stylu ukázala, že v 15 zemích Evropy (včetně ČR) byl komplexní rehabilitační program poskytnut pouze jedné třetině pacientů. ${ }^{(13)}$ Rehabilitace po akutní koronární příhodě se tradičně zaměřuje na cvičení a zvýšení tělesné aktivity. Nedávná metaanalýza 8940 pacientů zařazených do 48 programů kardiální rehabilitace ukázala, že komplexní rehabilitační péčí, včetně psychologické rehabilitace, lze ve srovnání se standardní péčí po akutní koronární př́íhodě snížit celkovou mortalitu o $20 \%$ a kardiovaskulární mortalitu o $26 \%$. $^{(14)}$

Je zřejmé že komplexní rehabilitační program je u našich pacientů poskytován pouze těm, kteří prodělají lázeňskou léčbu. Jsou to v naprosté většině nemocní po koronárním bypassu a zřídka po angioplastice. Také celý program EuroAction je zaměřen na pacienty po akutních koronárních příhodách a revaskularizačních procedurách. Existují snahy provádět rehabilitační programy inprimární, respektive zaměřit se na intermediární prevenci u osob bez klinicky prokázané arterosklerotické vaskulární nemoci, ale s vysokým globálním rizikem (> $5 \%$ ) podle tabulky SCORE.(15)

Existuje jen málo úspěšných programů komplexní rehabilitace a intervence standardních rizikových faktorů. Jednou z nich je Adventist Heart Study, do níž patř́i zřejmě i česká studie publikovaná v tomto čísle Cor et Vasa. Asi by zasloužila širší propagaci i v naší sekulární společnosti, která se s primární nedůvěrou dívá na jakýkoliv program organizovaný jakoukoliv náboženskou nebo nekomerční organizací.

Program NEW START v podstatě naplňuje Osackou deklaraci, ${ }^{(16)}$ a měl by být zařazen do preventivních programů IGA řízených Státním zdravotním ústavem.

\section{LITERATURA}

1. Wood DA, Kotseva K, Jennings C, et al. on behalf of the EUROACTION Study Group. EUROACTION: A European Society of Cardiology demonstration project in preventive cardiology. A cluster randomised controlled trial of a multi-disiplinary preventive cardiology programme for coronary patients, asymptomatic high risk individuals and their families. Summary of design, methodology, and outcomes. Eur Heart J Suppl 2004;6:Suppl J1.

2. Life style and risk factor management and use of drug therapies in coronary patients from 15 countries: Principal results from EUROASPIRE I and II. Euro Heart Survey Programme. Eur Heart J 2001;22:554-72.

3. Euroaspire Study Group. Clinical reality of coronary prevention guidelines. A comparison of EUROASPIRE I and II in 9 countries. Lancet 2001;357:995-1001.

4. Cífková R, a spol. Společná doporučení několika odborných společností pro prevenci kardiovaskulárních onemocnění v klinické praxi. Cor Vasa 2005; Suppl 9:3-14.

5. Filipovský J, Šimon J, Chrástek J, et al. Changes of blood pressure and lipid pattern during a physical training course in hypertensive subjects. Cardiology 1991;78:31-7.

6. Fraser GE. A comparison of first coronary heart disease rates in two contrasting California populations. J Nutr Health Aging 2005;9:53-8.

7. Willet W. Lessons from dietary studies in Adventists and questions for the future. Am J Clin Nutr 2003;78 (3 Suppl):539S-543S

8. Ornish D, Scherwitz LW, Billings JH, et al. Intensive lifestyle changes for reversal of coronary heart disease. JAMA 1998;280:2001-7.

9. Fraser GE, Shavlik DJ. Risk factors for all-cause and coronaty heart disease mortality in the oldest-old. The Adventist Health Study. Arch Intern Med 1997;157: 2249-58.

10. Weisburger JH. Lifestyl health a disease prevention: the underlying mechanisms. Eur J Cancer Prev 2002;11 Suppl 2:S1-S7.

11. Krajčovičová-Kudláčková $M$, Blažíček $P$, Dušinská $M$. Insulin resistance and nutrition. Cor Vasa 2004;46:393-6.

12. Slavíček J, Kittnar O, Medová E, a spol. Snížení rizikových faktorů kardiovaskulárních chorob životním stylem. Cor Vasa 2007;49:88-91.

13. Kotseva K, Wood DA, De Bacquer D, et al. Cardiac rehabilitation for coronary patients: lifestyle, risk factor and therapeutic management. Results from the EUROASPIRE II survey. Eur Heart J 2004;6 Suppl J:J17-J26.

14. Taylor RS, Brown A, Ebrahim S, et al. Execise-based rehabilitation for patients with coronary heart disease: systematic review and meta-analysis of rabdomized controlled trials. Am J Med 2004;1 16:783-92.

15. Favre A, Monpere C, Voyer C, et al. How to improve primary prevention in asymptomatic high risk subjects? Eur Heart J 2004;6 Suppl J:J59-J63.

16. The Osaka Declaration. Declaration of the fourth International Heart Health conference. Osaka, Japan, May 2001. 